\title{
Patrizio Tucci, «Adevinez, je vous en prye». L'écriture allusive chez Charles d'Orléans
}

\section{Maria Colombo Timelli}

\section{(2) OpenEdition}

1 Journals

\section{Édition électronique}

URL : https://journals.openedition.org/studifrancesi/40377

DOI : $10.4000 /$ studifrancesi.40377

ISSN : 2427-5856

Éditeur

Rosenberg \& Sellier

\section{Édition imprimée}

Date de publication : 1 juillet 2004

Pagination : 164

ISSN : 0039-2944

\section{Référence électronique}

Maria Colombo Timelli, « Patrizio Tucci, «Adevinez, je vous en prye». L'écriture allusive chez Charles d'Orléans », Studi Francesi [En ligne], 142 (XLVIII | I) | 2004, mis en ligne le 30 novembre 2015, consulté le 09 septembre 2021. URL : http://journals.openedition.org/studifrancesi/40377 ; DOI : https:// doi.org/10.4000/studifrancesi.40377

Ce document a été généré automatiquement le 9 septembre 2021.

\section{(c)}

Studi Francesi è distribuita con Licenza Creative Commons Attribuzione - Non commerciale - Non opere derivate 4.0 Internazionale. 


\title{
Patrizio Tucci, «Adevinez, je vous en prye». L'écriture allusive chez Charles d'Orléans
}

\author{
Maria Colombo Timelli
}

\section{RÉFÉRENCE}

PATRIZIO TUCCI, «Adevinez, je vous en prye». L'écriture allusive chez Charles d'Orléans, in L'allusion dans la littérature, Actes du XXIV ${ }^{\mathrm{e}}$ Congrès de la Società Universitaria per gli Studi di Lingua e Letteratura Francese (SUSLLF), en Sorbonne, novembre 1998. Textes réunis par Michel MURAT. Paris, Presses de l'Université de Paris-Sorbonne, 2000, pp. 41-66.

1 Article très intéressant, où la pratique de l'allusion, fondamentale dans l'œuvre de Charles d'Orléans, est mise en rapport avec les théorisations classiques et médiévales des procédés rhétoriques. De nombreux exemples, tirés aussi bien des poèmes «de l'exil» que des poèmes composés à Blois, et avec une attention toute particulière à l'égard du manuscrit autographe, montrent les différents emplois de l'allusion chez le prince-poète: allusion à d'autres textes d'abord (qui peut-être tous ne sont pas conservés), allusion à des moments particuliers de la vie de Charles (de la prison à la vieillesse), allusion à des «personnages», voire à des personnalités connues et non mentionnées. Le lecteur peut être invité à se faire complice de ce qui est dit, et surtout de ce qui n'est pas dit; toujours prêt à se faire exégète, il doit surtout éviter le risque de surinterpréter le texte. Reste cependant la question primordiale, que Patrizio Tucci pose en conclusion: le critique doit bien se demander si, par le dévoilement complet de leur sens, les poèmes de Charles d'Orléans «gagneraient ou perdraient au change» (p. 66). 